\title{
JUDICIAL ENFORCEMENT BY SOCIAL ASPECTS
}

\author{
Written by: Eszter dr. Sőréné dr. Batka ${ }^{1}$
}

"Silence in the face of evil is itself evil: God will nothold us guiltiness. Not to speak is to speak. "Not to act is to act".

Dietrich Bonhoeffer

\section{Introduction}

Nowadays, mortality loses its importance. Moral behaviour, and religion have become an alternative. In the public consciousness, religion and morality play second fiddle to law, which is contrary to the use of public discourse. ${ }^{2}$ In every rule of law, however, law and its enforcement not a matter of choice. Law is mandatory for all people without exception - as The Fundamental Law of Hungary also sets it out.

The main objective of my study is to combine the judicial enforcement with the social network in Hungary, as a system, based on solidarity, given that no particular attention has been paid to this so far. Apart from some measures (debt management programme, National Asset Management Programme), the involvement of the social network in the enforcement procedure has not taken place, although it could be extremely important in particular when judgment debtors are on the verge of eviction.

\footnotetext{
${ }^{1} \mathrm{PhD}$ student, Károli Gá spár University of the Reformed Church, Consultant: Dr. Habil Birher Nándor, Head of Department, Department of Law Theory and Church Law

${ }^{2}$ Nándor Birher(2021.) Value-based a dministration.p. 22. (manuscript)
} 


\section{Solidarity}

"Solidarity" is a bit worn and sometimes misinterpreted, but much more than a few sporadic acts of generosity. Calls for a new mentality, ${ }^{3}$

Solidarity is also known, as the power of humanity. Solidarity has many meanings, as many people are alive nowadays. We are different, we do not have the same opinions in certain topics, and that is the way it has to be! However, there is mostly one thing which is the same in us: that we are all human beings.

In the social teaching of the Church, the values of freedom and responsibility, justice and solidarity strike a balance between the individual and the community, which frees man from the effects that impede the conditions of physical and spiritual existence. This harmonious state of development is called the public good of Catholic social teaching. According to Habermas, "the social integration power of the law ultimately decides to the sources of social solidarity." 4

Protection should be given to those who really wants to cooperate and "deserves" help, so only those should be protected from forced evictions. Unfortunately, practical experience shows that many people are abusing the benefits granted to them. If people would know and learn how to cooperate or they would have at least the will to stand in with the bailiffes and the creditor, that would be a bigger chance for them not to lose their home. Or if lost, get another one to live in. Having adequate housing is a fundamental human right and a basic human need. Without enough financial support and cooperation, the fate of the evicted people is unfortunately sealed in many cases. The principle of solidarity as a normative social principle is, above all, a principle of law, stresses Nell Breuning. ${ }^{5}$

The aim of solidarity is to encourage each other, to think rightfully and take care of each another in a fair way. Solidarity works best when we respect each other's different needs and living conditions, understand that there are many ways of solidarity and coordinate our responses.

\footnotetext{
${ }^{3}$ Evangelii Gaudium (2013) (https://katolikus.hu/dokumentumtar/2979) (20.05.2021.)

${ }^{4}$ Ha bermas Jürgen (1992) Faktizitat und Geltung. Beitrage zur Diskurstheorie des Rechts und des demokratischen Rechst. Vandenhoeck \& Ruprecht (GmbH\& Co. KG) (ed.) p. 282.

${ }^{5}$ Anzenbacher Arno (2001.) Christian Social Ethics. Szent Ist ván Társulat (ed.) p. 188.
} 
Solidarity should therefore be a mutual commitment and a willingness to help one another in the communities of people, which, as I can see, is a small presence in today's societies.

As I have already mentioned, having adequate housing and shelter is a fundamental human right and a basic human need. It therefore can be seen in many cases, that without having a proper home and assistance, the problem will only continue to spread. If there is no financial backing, the standard of living will decline, the absence of one fundamental human right causes another to be marginalised. We should just think it over, if the social situation of a parent or the parents deteriorates that will jeopardize the mental, physical wellbeing of the children, raised in the family. Problem creates problem.

Arguably plausible solution is the search for a scapegoat, the objectified form of which is the bailiff, the Judge or even the Notary.

In view of the viral situation, judgment debtors receive a number of benefits. However, the 'favourable' measures do not last forever. It is important to keep in mind, which people often forget about, that discounts do not affect interest rates! After the State of Danger will be over, the proceedings will continue, and it is impossible for many obligors to repay debts which have increased significantly as a result of the lack of repayments.

Unfortunately, in Hungary, the involvement of social workers has not been achieved at all in the area of implementation, despite the fact, that there is often a lack of awareness and total desperation among in this segment of society, which could be improved with the right measures. Lack of information always creates problems to be addressed. Above all, it would be important to inform people properly, to identify problems, to raise awareness of the consequences. As I can see, a significant proportion of the procedures would not even reach the auction process if communication were to function properly. However, mutual cooperation between the parties would be necessary to achieve this.

Building a completely new social model alway s costs a lot, problems need to be solved, and only from exclusive public funding cannot be expected. In my view, a solidarity-based social network - linked to the implementation procedure - would and could be needed to create. Given that I am working as an assistant bailiff, I see several opportunities to build a system based on a social basis, that based on solidarity. 


\section{Social norms}

Sociology is a study of the laws of social life. Anyone who is familiar with sociology is likely to understand society better. It has the ability to defend itself against manipulative, misleading views and to provide some clues to individuals in society who are not well versed in sociology. ${ }^{6}$ The social preferences of the state, the traditions of its administrative system, have a major influence on a state's welfare system, reflecting traditions, but sometimes even independent of them. The extent of social solidarity and the sharing of responsibility greatly influence what societies prefer. In a society it is also relevant to how do members feel about whether an individual in a difficult situation should be assisted by the family, civil society, voluntary organisations, the state or the individual itself. Some studies suggest that, like other formersocialist countries, solidarity is stronger in Hungary than in Western Europe, but at the same time slightly weaker than in its eastern neighbours. ${ }^{7}$

Education is as many as there are in society, and therefore people react differently to different events. Each society develops its own person of ideas, that is, what man should be like from a spiritual, physical and moral point of view. To some extent, this ideal should be the same for all citizens. This ideal is differentiated only at some point, in accordance with the specific environments that every society carries. A person's physical, mental, moral skills, which are expected of him in general by the political society and, in particular, the specific environment to which he belongs, are nurtured in childhood by the adult generation in the process of education. ${ }^{8}$ Education is therefore the socialisation of the young generation and the empowerment of the individual, enriched with moral values, to become an appropriate member of that society. Unlike the pursuit of physical and mental abilities, the development of which depends on the individual's internal motivation, the moral qualities of people can only be developed for external influence. Moral qualities require abstinence from the individual on numerous times, thus disturbing his natural movement. Man is actually only human because he lives in society. Morality therefore comes from community life.${ }^{9}$ Human society is a group of free beings. Every member of society has demands, big or small, but they determine the viability

\footnotetext{
${ }^{6}$ Rudolf Andorka (2006.) Introduction to sociology. Osiris (ed.), Budapest.

${ }^{7}$ Ákos Rédey, Anett Utasi (2012): Socially sensitive environment development, Pannon University, (https://regi.tankony vtar.hu/hu/tartalom/tamop412A/2010-0012_szocialisan_erzekeny_kornyezet/ch02.html) (28.02.2021.)

${ }^{8}$ Dürkheim Émile (1980.) Education and Sociology. Tankönyvkiadó(ed.), Budapest, p. 20-21.

${ }^{9}$ (Dürkheim, 1980.p. 25.)
} 
of society. But society draws a path, in this sense we fulfil our duty without any particular effort. ${ }^{10}$

Social norms represent a set of rules governing the collective behaviour and behaviour of social groups and human communities. Human norms, the formation of our consciousness, made the human race so viable ${ }^{11}$, but in today's society that certain "us consciousness" seems to fade, the self-interests that can lead to the fragmentation of society are coming to the fore.

Social cooperation is not a small task when you think about the fact that even within the family there are countless disagreements in everyday life. In my view, unfortunately, most people usually think when a particular problem arises: why should I be the one to make the world a better place, watch out for the other one? In Hungary, we tend to shift responsibility to each other, to blame the other for the problems that arise. People usually look at why and what the other has, instead of subject themselves to self-criticism and try to find a way out of the situation.

What are the most characteristic of societies? Conflict, or cooperation and harmony?

According to harmony theories, societies are characterised by cooperation, and conflict is only present in exceptional cases. On the other hand, according to conflict theories, societies are characterised by conflicts, which are not necessarily the necessary evil, but society evolves through them. Without conflicts, society is stagnating.

There are exchange theories, according to which members of society exchange goods - not only material, but mentally, spiritually - such as respect, love, obedience. According to forced theories, the exchange, which brings benefits to all, is more characterised by the pressure applied to the oppressed, since the exchange is not equal, but through coercion, through the transfer of unequal goods. ${ }^{12}$

\footnotetext{
${ }^{10}$ HenriBergson (2002.) Two sources of morality and religion. Szent István Társulat (ed.), Budapest, p. 9-32. ${ }^{11}$ Nándor Birher (2020) Community Rules (http://epa.oszk.hu/02000/02065/00005/pdf/EPA02065_gazdasagetika_2013_05_birher\%20nandor_\%20a\%20ko zosseg\%20szabalyai.pdf) (28.03.2021.)

${ }^{12}$ (Andorka, 2006, p. 24.)
} 
I think not only the society of our country, but the society of the world in general, is composed of different layers. The economic crisis in 2020, given the extreme situation caused by Covid19, has now surpassed the crisis of 2008.

By quantifying the evolution of cases in recent years, it is clear that the figures for enforcement cases launched in the country show evenly high figures, compared to this the number of evictions is much lower. However, the data on the number of evictions in statistics relates only to forced evictions and possessions but does not include the number of voluntary evictions and thus provides somewhat misleading data's. 
1 st table: Number of enforcement proceedings initiated from 2018 to 2021. in the first quarter

\begin{tabular}{|c|c|}
\hline Period (year) & Number of cases opened (pc) \\
\hline 2021.1 st quarter & 211.452 \\
\hline 2020 & 735.279 \\
\hline 2019 & 730.293 \\
\hline 2018 & 734.507 \\
\hline
\end{tabular}

Source: Own work based on the statistical report of the Ministry of Justice

2nd table: Evolution of evictions 2016-2021. in the first quarter

\begin{tabular}{|c|c|c|c|}
\hline $\begin{array}{c}\text { Period } \\
(\text { year })\end{array}$ & $\begin{array}{c}\text { Possession after } \\
\text { Successful auction of } \\
\text { residential property } \\
(\mathbf{p c})\end{array}$ & $\begin{array}{c}\text { Other (Vht. Section } \\
\mathbf{1 8 1} \text { Section 183 } \\
\text { Section 183/C) }\end{array}$ & $\begin{array}{c}\text { Total } \\
(\mathbf{p c})\end{array}$ \\
\hline 2021,1 st quarter & 29 & 13 & 42 \\
\hline 2020 & 1.115 & 530 & 1.645 \\
\hline 2019 & 2.088 & 1.029 & 3.117 \\
\hline 2018 & 1.928 & 1.284 & 3.212 \\
\hline 2017 & 2.350 & 1.317 & 3.667 \\
\hline 2016 & 1.734 & 1.740 & 3.474 \\
\hline
\end{tabular}

Source: own work based on the statistical report of the Hungarian Association of Court Bailiffs 
As a result of the situation, social groups have faced an even greater crisis. Different groups of society have different social assets, so they also occupy different places in society. Consequently, some groups are fairly stable, and others are unstable and vulnerable. ${ }^{13}$

The Constitution of 1989 saw social security as the right of citizens, but the newly adopted basic law abolished this status and refers to social security as a goal to be achieved. ${ }^{14} \mathrm{As}$ a result of these processes, the situation of those at the bottom is vulnerable not only by their scarce resources, but also their legal status is challenged, which makes their non - privileged position in society's inequality even more uncertain. ${ }^{15}$

The development of the Hungarian social system, the models of welfare states, demographic changes, the development of social care and social network are dealt with by many authors, number of literatures, I mean without the need for completeness Mihály Nyilas, Rudolf Andorka, Zsuzsa Ferge, or Émile Dürkheim and Max Weber. But the cooperation of the social network with enforcement procedures has not yet occurred anywhere.

At the time of the amendment of Act III of 1993 on Social Administration and Social Benefits in 2001, the debt management service in Hungary was already regulated at the legal level. The service started operating in 2003, but on 1 March 2015 the debt management service was removed from the legislation. The operation of the debt management service was part of the responsibility of the Mayor's Offices. ${ }^{16}$

The purpose of the Social Act, similar to Act CV 2015 on the settlement of debt suppleant by natural persons which was published on 8 July 2015, was to restore ${ }^{17}$ the judgment debtor's

\footnotetext{
${ }^{13}$ Ákos Huszár (2011.) Proof of social stratification and inequalities, vulnerable groups in Hungarian society. In Szociológiai Szemle 2011/3.p. 108.

${ }^{14}$ (Huszár, p. 124.)

${ }^{15}$ Júlia Sza lai (2007.) Aren't there two countries...?Social struggles for state (over)distribution in Hungary after the change of regime. Osiris (ed.), Budapest.

${ }^{16}$ Katalin Lunkán (2015.) Debt management - on the margin of an abandoned social service, (https://arsboni.hu/adossagkezeles-egy-megszuntetett-szocialis-szolgaltatas-margojara/ ) (28.03.2021.)

${ }^{17}$ the basic difference, however, the Act CV 2015 on the settlement of debt suppleant by natural persons. Pursuant to Para graph 28, enforcement actions may notbe carried out in enforcement proceedings: 'As from the receipt by the enforcer of the notification of the lod ging of the debt settlement initiative, the act of procedure or a ction taken aga inst the judgment debtor, the guarantor, other joint and several judgment debtors and the obliga tion in rem in progress in the enforcement proceedings for the recovery of claim s against them shall not be taken, and the declarations made by the parties and other obligors during the period of cessation shall be ineffective; from that date, all the deadlines will be set. The acting bailiff shall not beentitled to issue a fee list in view of the interruption. Subsequently, nofurther auction notices may be published in the enforcement procedure, on the basis of the auction notice already published before the cessation, the bailiff shall conduct the auction once the bidding has a ready begun, and a valid bidding offer has been received.'
} 
solvency and, in addition to financial support, was to 'remove' the client from the situation into which he fell. The emphasis was placed on being an active contributor to solving his own problem.

Unfortunately, it was not possible to find the perfect solution during several recasts of the regulation, so the programme was removed from the legislation from 1 March 2015. In my view, it could also be a problem that people who would have been speculatively trying to reduce their debts or would not cooperated with the benefits may have caused problems. I believe that with the close cooperation of the Mayor's Offices, the charitable organisations and the bailiffs, a social system in which the really needy party would be able to take advantage of the opportunities provided, since the bailiff has the greatest insight into the financial situation of judgment debtors and even their personality. Consequently, the bailiff is able to propose who is "worthy" for support, assistance, from whom the necessary contribution can be achieved.

\section{Welfare States}

In parallel with the emergence of a modern state organisation, welfare states were created, which can be regarded as post-World War II phenomena. ${ }^{18}$ Today, every developed state considers itself a welfare state. ${ }^{19}$ Social administration plays an important role in the model of all welf are states, although the systems are different, as we distinguish different social models. Although the obligation to care had already appeared in Roman law, in terms of cliens, the conditions ${ }^{20}$ for the development of state-organised social policy in the 19th century were created by civil and industrial revolutions ${ }^{21}$, which evolved differently in different countries of different continents. Social policy was completed in the 20th century. The 1891st edition of the century was of great importance. The Encyclical Rerum Novarum issued by Pope Leo. The Encyclic encourages that in economic life moral laws also apply, and in economic life one cannot forget that man is the first. The goods are for man, not man for goods. Therefore, in

\footnotetext{
${ }^{18}$ Mihály Nyilas (2009) The Welfare State in the 21stCentury, Budapest, Hilsher Rezső Szociálpolitikai Egyesület (ed.), Buda pest, p.21.

${ }^{19}$ Ba lázs Krémer (2009.) An Introduction to Social Policy. Napvilág (ed.), Budapest, p. 123.

${ }^{20}$ the prominent, influential, ancient Romans took certain persons, sometimes whole communities, into their patronage, these were cliens. These cliens were then loyal and obedient to the patrons. They were accompanied, voted for in elections...For a long time, the cliens were probably not a full citizen, but from 400 B.C. they did. After the beginning of the Empire, the cliens-Patronus relationship gra dually lost its significance. There was also a patromus-client relationship between Rome and the smaller states that recognised Rome's sovereignty. These states were usually obliged to send troops to the Roman army. The other name of the kingdom thus conquered was the cliens-kingdom.(https://jaszmoni.eoldal.hu/cikkek/egyeb/roma-fogalmak-i_.html) (2021.03.14.)

${ }^{21}$ István Hoffmann (2015.) Introduction to Social La w. ELTE Eötvös (ed.), Budapest, p. 11.
} 
social life, the primate belongs to the community, not the individual's. Around the implementation of the Community principle, the State, as the highest representative of the Community principle 22 , is responsible for important tasks. The Encyclical of Pope Pius's 1931 Quadragesimo Anno. The Encyclical states that, in fact, a radical transformation of the economic structure and the creation of a new social order are needed, i.e., structural, mental, and moral improvement. ${ }^{23}$

\section{Serving the Poor in the Church - Caritas}

Throughout its history, the Church has never failed to speak out on the issues of social life, which was the subject of the XIII. Pope Leo also has a duty to articulat. ${ }^{24}$

The life of the ancient Christian parishes, following the example of Jesus Christ's life, was utterly interwoven by helping the fallen (gathering for the poor, redeeming slaves, supporting widows). The obligation to care for relatives and the compulsory work of those who could work were among the principles of the ancient church. The ecclesiastical community fully supported the incapacitated if they had no relatives. Within the community, there was a full-scale poverty relief system, which was already in place. In addition to caring for the body and physical needs, the community also nurtured the souls of their poor companion. The aid was made out of the faithful's donations. The method of donation was the voluntary donation of the oblatio. Even in ancient times, the Church extended the scope of poor care beyond the borders of the Roman Empire. A quarter of the ecclesiastical possessions of the "quarta pauperum" had to be used for charitable purposes, with church "parents" and inns capable of receiving the poor. ${ }^{25}$

Ecclesiastical care has achieved amazing results over time, and in Europe it now forms national organisations. Catholic Caritas in Hungary is a humanitarian organisation with a religious legal personality, helping those in need regardless of age, gender, or denomination. This is done together with social institutions, aid schemes, donations, volunteers.

\footnotetext{
${ }^{22}$ Béla Földes, The Importance of Rerum Novarum (https://mtda.hu/ADATTAR/cikktar/f_cikk/foldes_bela_a_rerum_novarum_jelentosege.pdf) (28.03.2021.) ${ }^{23}$ Encyclical of Pope Pius XI on reconstruction of the social order to our venerable brethren, the patria rchs, primates, archbishops, bishops, and other ordinaries in peace and communion with the a postolic see, and likewise to all the faithful of the Catholic World.(1931.) (http://www.vatican.va/content/piusxi/en/encyclicals/documents/hf_p-xi_enc_19310515_quadragesimo-anno.html)(14.03.2021.) ${ }^{24}$ The Compendium of the Church's Social Tea ching. (2013.) (https://www.vatican.va/roman_curia/pontifical_councils/justpeace/documents/rc_pc_justpeace_doc_20060526_ compendio-dott-soc_hu.html) (05.06.2021.)

${ }^{25}$ (https://karitasz.hu/karitaszrol/tortenet) (05.06.2021.)
} 


\section{The Maltese Charity Service - "Tuitio fidei et obsequium pauperum".}

The organisation was founded in Hungary on 4 February 1989. The initiative was based on the establishment of the Charity Service in 1986, when the Association of Hungarian Knights of Malta considered it necessary to launch a broader health action. The goal was to help doctors. Csilla von Boeselager, a Hungarian chemist, and Imre Kozma, a Roman Catholic priest, grew into an intensive charitable organisation. The Charity Service collects donations in kind, which are used for public purposes. It provides direct aid to those in need, as well as the institutions that provide them. They organise intellectual programmes to promote cooperation between different sectors of society and to strive for social security. They provide families, old people, homeless people, and help them with advice. The organisation also has an ambulance service. Like Caritas, it has few employees, but more volunteer members. ${ }^{26}$

\section{The Mayor's Offices}

Local governments, on their own account, within the framework of the laws, regulate and manage local public affairs within their respective responsibilities and competences. Local governments perform mandatory and voluntary tasks in the administration of public affairs. It is the duty of every local government to perform the mandatory tasks, which is independent of the size of the Mayor's Office and its capacity to hold burdens. All Mayor's Office must therefore ensure that residents have access to the services listed in the Act.

However, local governments are free to assume tasks which are not solely within the competence of another body. However, these activities should not jeopardise the performance of the tasks to be carried out or financed only from the revenues of the Mayor's Office and the resources provided for this purpose. Though, they can own their property, own their own budget, or even undertake their assets. ${ }^{27}$

The Fundamental Law of Hungary attaches particular importance to the protection of Christian culture and institutional cooperation with historical churches and their social service. In the

\footnotetext{
26 (Https: //www.maltai.hu/) (22.06.2021.)

27 (Https://2010-2014.kormany.hu/hu/mo/onkorman yzatisag-magyarorszagon) (13.03.2021.)
} 
preamble to the Charter, the National Creed, which highlights the role of Christendom as a national preserver, is formulated. ${ }^{28}$

In view of the fact that local governments are free to interrogate tasks, they could, in my view, be involved in the implementation process in close cooperation with the bailiffes, as well as the Catholic Caritas organisation operating in Hungary and the Maltese Charity Service. I believe that spiritual assistance and listening to problems can be of great importance, which can greatly help obligors to try to find solutions to their problems that seem hopeless. Dietrich Bonhoeffer said, "The first service he owes to someone else in the community is to listen to them. As God's love begins with hearing his word, so the beginning of love for our brothers learns to listen." I mean that they could provide judgment debtors with information on enforcement procedures in general, including the possibility of payment of instalments in the course of the procedure and the consequences of not taking it seriously and ignoring their debt. Although already section one of the Act LIII of 1994 on Judicial Enforcement provides for the role of bailiff in proceedings, this is not clear to respondents. Moreover, both the debt and the procedural acts are held responsible by the bailiff, i.e., the bailiff is the necessary evil, whereas the 'Lord of the Case' is the creditor. The role of the bailiff is more like the role of a mediator who enforces decisions of the court or other bodies within the legal framework. Unfortunately, experience shows that judgment debtors believe other persons - be it for enforcement, court or even a third party - rather than the bailiffes.

The interconnection of systems would provide a solution in terms of financial background as well as adequate information and spiritual assistance, which would provide a continuous source of revenue. The establishment of the network would be in line with the objective of government policy since the central issue in Hungary is to reform and make it more effective in the implementation procedures for the recovery of family support and even the single parent maintenance fee. I believe that the right motivation, targeted communication, the flow of information, counselling and financial assistance will lead to positive changes.

\footnotetext{
${ }^{28}$ Nándor Birher-Árpád Homicskó(2021.) Control Complexity. Pa trocinium (ed.), Budapest. p. 49.
} 
The creation of a social system based on solidarity would require a redistribution of existing resources, which would enable the system to operate without any particular additional expenditure from the State. ${ }^{29}$

\section{Summary}

In the Church's social teaching, the values of freedom and responsibility, justice and solidarity create a balance between the individual and the community, which frees man from the influences that hinder his physical and spiritual conditions ${ }^{30}$.

This harmonious state open to development is called the common good of Catholic social teaching.

According to Habermas, "the social integration power of law ultimately derives from the sources of social solidarity ${ }^{31}$.

In addition to developing mutual solidarity, there should be protection on the subject, so that everyone is protected against forced evictions, or at least there should be a solution for them to live somewhere else. Having adequate housing and shelter is a fundamental human right and a fundamental human need.

However, in many cases, the fate of evicted people is, unfortunately, sealed without adequate financial background and cooperation.

By exploiting the resources available to us, the social fund created by establishing a solidaritybased financing system can provide assistance to individuals who are actually in need and cooperate, even in the present situation. We should bear in mind „True morality is not a simple "“'you" relationship, but a complex "we" relationship". 32

Finally, I would like to end my thoughts with a quote:

\footnotetext{
${ }^{29}$ Eszter Sőréné Batka (2021.) Juditial enforcement, eviction. Could it be different? In Studia Wesprimiensia, A Veszprémi ÉrsekiFőiskola Folyóirata (ed.), Veszprém, p. 275.

${ }^{30}$ (http://www.ncsszi.hu/download.php?file_id=973)(25.06.2021.)

${ }^{31}$ (Habermas, 1992.)

${ }^{32}$ Ná ndor Birher - Árpád Homicskó (2020.) Manual for ecclesiastical institutions, KRE-ÁJK, Prof. Dr. MiskolcziBodnár Péter dean(ed.), Budapest.
} 
The task is not to overturn the world, but to do what is necessary objectively and truly in a given place, from the point of view of reality. ${ }^{33}$

Dietrich Bonhoeffer

\section{Literature}

Ákos Huszár (2011.) Proof of social stratification and inequalities, vulnerable groups in Hungarian society. [A társadalmi rétegződés és az egyenlőtlenségek igazolása, Sérülékeny csoportok a magyar társadalomban] In Sociológiai Szemle 2011/3.p. 108.

Anzenbacher Arno (2001.) Christian Social Ethics. [Keresztény társadalometika] Szent István Társulat (ed.) p. 188.

Balázs Krémer (2009.) An Introduction to Social Policy. [Bevezetés a szociálpolitikába] Napvilág (ed.), Budapest, p. 123.

Dürkheim Émile (1980.) Education and Sociology. [Nevelés és szociológia] Tankönyvkiadó (ed.), Budapest, p. 20-21.

Eszter Sőréné Batka (2021.) Juditial enforcement, eviction. Could it be different? [Végrehajtás kilakoltatás. Lehet másképp?] In Studia Wesprimiensia, A Veszprémi Érseki Főiskola Folyóirata (ed.), Veszprém, p. 275.

Habermas Jürgen (1992) Faktizitat und Geltung. Beitrage zur Diskurstheorie des Rechts und des demokratischen Rechst. Vandenhoeck \& Ruprecht (GmbH \& Co. KG) (ed.) p. 282.

Henri Bergson (2002.) Two sources of morality and religion. [Az erkölcs és a vallás két forrása] Szent István Társulat (ed.), Budapest, p. 9-32.

\footnotetext{
${ }^{33}$ The best quotes of Dietrich Bonhoeffer (https://vi.nuncajamasyyo.com/106-best-dietrich-bonhoeffer-quotes) (18.06.2021.)
} 
Júlia Szalai (2007.) Aren't there two countries...? Social struggles for state (over)distribution in Hungary after the change of regime. [Nincs két ország...? Társadalmi küzdelmek az állami (túl)elosztásért a rendszerváltás utáni Magyarországon] Osiris (ed.), Budapest.

Mihály Nyilas (2009) The Welfare State in the 21st Century, [A jóléti állam a 21. században] Budapest, Hilsher Rezső Szociálpolitikai egyesület (ed.), Budapest, p.21.

Nándor Birher - Árpád Homicskó (2021.) Control Complexity. [Szabályozáskomplexitás] Patrocinium (ed.), Budapest. p. 49.

Nándor Birher (2021.) Value-based administration. [Értékalapú közigazgatás] p. 22. (manuscript)

Nándor Birher - Árpád Homicskó (2020.) Manual for ecclesiastical institutions, [Kézikönyv az egyházi fenntartású intézmények számára] KRE-ÁJK, Prof. Dr. Miskolczi-Bodnár Péter dean (ed.), Budapest.

Rudolf Andorka (2006.) Introduction to sociology. [Bevezetés a szociológiába] Osiris (ed.), Budapest.

\section{Links}

Ákos Rédey, Anett Utasi (2012): Socially sensitive environment development, [Szociálisan érzékeny környezet fejlesztés] Pannon University, (https://regi.tankonyvtar.hu/hu/tartalom/tamop412A/2010 0012_szocialisan_erzekeny_kornyezet/ch02.html) (28.02.2021.)

Béla Földes, The Importance of Rerum Novarum [A Rerum Novarum jelentősége] (https://mtda.hu/ADATTAR/cikktar/f_cikk/foldes_bela_a_rerum_novarum_jelentosege.pdf) (28.03.2021.)

Encyclical of Pope Pius XI on reconstruction of the social order to our venerable brethren, the patriarchs, primates, archbishops, bishops, and other ordinaries in peace and comunion with the apostolic see, and likewise to all the faithful of the Chatolic World. (1931.) 
(http://www.vatican.va/content/pius-xi/en/encyclicals/documents/hf_p-

xi_enc_19310515_quadragesimo-anno.html) (14.03.2021.)

Evangelii Gaudium (2013) (https://katolikus.hu/dokumentumtar/2979) (20.05.2021.)

István Hoffmann (2015.) Introduction to Social Law. [Bevezetés a szociális jogba] ELTE Eötvös (ed.), Budapest, p. 11.

Katalin Lunkán (2015.) Debt management - on the margin of an abandoned social service.

[Adósságkezelés - egy megszüntetett szociális szolgáltatás margójára

] (https://arsboni.hu/adossagkezeles-egy-megszuntetett-szocialis-szolgaltatas-margojara/ ) (28.03.2021.)

(https://karitasz.hu/karitaszrol/tortenet) (05.06.2021.)

(Https://2010-2014.kormany.hu/hu/mo/onkormanyzatisag-magyarorszagon) (13.03.2021.)

(Https: //www.maltai.hu/) (22.06.2021 .)

(http://www.ncsszi.hu/download.php?file_id=973) (25.06.2021.)

Nándor Birher (2020) Community Rules [A közösség szabályai] (http://epa.oszk.hu/02000/02065/00005/pdf/EPA02065_gazdasagetika_2013_05_birher\%20n andor_\%20a\%20kozosseg\%20szabalyai.pdf) (28.03.2021.)

The best quotes of Dietrich Bonhoeffer (https://vi.nuncajamasyyo.com/106-best-dietrichbonhoeffer-quotes) (18.06.2021.)

The Compendium of the Church's Social Teaching. [Az egyház társadalmi tanításának kompendiuma]

(https://www.vatican.va/roman_curia/pontifical_councils/justpeace/documents/rc_pc_justpeac e_doc_20060526_compendio-dott-soc_hu.html) (05.06.2021.) 